Andrews University

Digital Commons @ Andrews University

Faculty Publications

$1-1-2009$

\title{
Assisting and Protecting Refugee Women: A Policy Analysis
}

\author{
Barbara J. Kampa \\ Andrews University \\ Raphael Nawrotzki \\ Andrews University
}

Follow this and additional works at: https://digitalcommons.andrews.edu/pubs

Part of the Migration Studies Commons

\section{Recommended Citation}

Kampa, Barbara J. and Nawrotzki, Raphael, "Assisting and Protecting Refugee Women: A Policy Analysis" (2009). Faculty Publications. 1837.

https://digitalcommons.andrews.edu/pubs/1837

This Article is brought to you for free and open access by Digital Commons @ Andrews University. It has been accepted for inclusion in Faculty Publications by an authorized administrator of Digital Commons @ Andrews University. For more information, please contact repository@andrews.edu. 
See discussions, stats, and author profiles for this publication at: https://www.researchgate.net/publication/260598414

\section{Assisting and protecting refugee women: A policy analysis}

Article $\cdot$ January 2009

CITATIONS

0

2 authors, including:

Raphael Nawrotzki

German Institute for Development Evaluations (DEval)

52 PUBLICATIONS 881 CITATIONS

SEE PROFILE

Some of the authors of this publication are also working on these related projects:

READS

222

Resilience Academy View project

Climate variability and mortality in Sub-Saharan Africa through demography View project 
Accepted pre-typeset version of article published as:

Kampa, B. J., \& Nawrotzki, R. J. (2009). Assisting and protecting refugee women: A policy analysis. International Journal of Interdisciplinary Social Sciences, 4(8), 39-50.

\title{
Assisting and Protecting Refugee Women: A Policy Analysis
}

\author{
Barbara J. Kampa and Raphael J. Nawrotzki
}

Andrews University

2009 


\title{
Assisting and Protecting Refugee Women: A Policy Analysis
}

\begin{abstract}
The number of refugees and internally displaced persons (IDPs) has risen sharply over the last decade. This trend is the result of several causes such as the impact of climatic change, conflicts over diminishing resources, and religious and ethical disagreements. The largest and most vulnerable subgroup among refugees is women and their dependent children, and they are frequently subject to abuse and neglect. To address protection issues, the United Nations High Commissioner for Refugees (UNHCR) released the Policy on Refugee Women in 1990. The authors provide a comprehensive policy analysis, building on an exploration of the historical background and a presentation of policy goals. This exploration sets the stage for a discussion of the influence and viewpoints of major interest groups, such as donors, governments, and non-governmental organizations. The authors draw upon case-studies and a variety of literary resources to explore diversity issues, social justice concerns, and ethical interests. Furthermore, the authors assess the policy's implementation success by using the categories of positive outcomes (institutional change, new programming tools, improvement in refugee situation) and unintended outcomes (cultural and religious opposition, onesidedness, and negative conception). Finally, the authors present a comparison of the applications and implications of the 1990 UNHCR Policy from a global perspective, focusing primarily on the United States, United Kingdom, and Canada as exemplary countries. The paper concludes with a set of recommendations for policy-makers and project managers to further improve protection and assistance programs that will further improve on meeting the needs of refugee women and girls worldwide.
\end{abstract}

\section{Keywords}

Refugee Women, Policy on Refugee Women, Social Justice, Intended Outcomes, Historical Background, Guidelines, Global Comparison 


\section{Assisting and Protecting Refugee Women: A Policy Analysis}

\section{Introduction}

For thousands of years, environmental changes, resource scarcity, and war and conflict resulting from political, religious, and ethical disagreements have forced people to flee their homes in search for a more secure dwelling. These refugees and internally displaced people face many hardships and are frequently exploited, harassed, and discriminated against. To provide the legal basis to protect the fundamental rights and freedoms of this vulnerable population, the United Nations (UN) created the 1951 Refugee Convention (UNHCR, 1951). Despite the instatement of this policy, a major fraction of the refugee population failed to receive adequate assistance and protection. According to Turner (2000), 75 percent of all refugees are women and their dependent children, and the 1951 UNHCR policy failed to address their specific needs.

Displacement has dramatically increased the number of female-headed households, leaving the women with added responsibilities for meeting the needs of children and aging relatives (Gururaja, 2000). Furthermore, women and girls are highly vulnerable, facing increased risk of abuse and sexual violence. For example, in 1993, 200 incidents of rape were reported from a single Somali refugee camp in Dadaab, Kenya (Mwangi Kagwanja, 2000). Sexual and genderbased violence (SGBV) amongst refugee women and girls is a major problem. Patriarchal ideologies and traditions have been the root cause of such acts (Weiss Fagen, 2002), During the second part of the twentieth century, ideologies began to change, but it was not until the 1970s that mainstreaming women's issues became the focus of policy makers (Jahan, 1996). As a result, the Convention on the Elimination of All Forms of Discrimination against Women (CEDAW) was adopted by the UN General Assembly in 1979 (UNHCR, 1979). The main goal was to place women's issues as a top priority to combat the deep-seated discrimination against them. Moreover, the goal of mainstreaming women was to help them set their own agenda according to their perceived needs, rather than having the agenda set for them by outsiders (Anderson, 1993). The significance of mainstreaming women was further underscored by the 1985 UN World Conference in Nairobi, Kenya, where the Nairobi Forward Looking Strategy for the Advancement of Women was adopted, which emphasized that any relief program would only be effective if women as the target population participated in the planning and implementing process.

The United Nations High Commissioner of Refugees (UNHCR) began to realize that refugee women and girls were not given the necessary protection and assistance they needed. In order to evaluate and analyze the gaps, UNHCR set up 
a working group comprised mostly of women considered to be of low status to investigate the issue (Berthiaume, 1995). These efforts led to several conclusions. No. 39: Refugee Women and International Protection, which stressed the need for special protection of this vulnerable subgroup of refugees, was UNHCR's first conclusion endorsed in 1985. Three other conclusions adopted in 1987, 1988, and 1989 respectively added details about the range of protection for refugee women and girls and the need for women to participate in the planning and execution of assistance programs (UNHCR, 1990). Finally, in 1990 the UNHCR Executive Committee adopted the Policy on Refugee Women (henceforth referred to as the Policy) followed by the Guidelines on the Protection of Refugee Women (henceforth referred to as the Guidelines) in 1991. The Guidelines emphasized the "intrinsic relationship...between protection and assistance" (Weiss Fagan, 2002, p. 1) and became the framework for the practical applications of the Policy in the field (UNHCR, 1991).

The following sections present the goals of the Policy and an assessment of its implementation. Furthermore, major interest groups and their attitudes towards the Policy are discussed. Included is an explanation of how the policy addresses issues of social justice and human rights in the context of existing and potential ethical dilemmas. In addition, the authors discuss intended and unintended outcomes and how well the United States, Canada, and the United Kingdom assist and protect refugee women in comparison to the governments where the majority of asylum-seekers originate.

\section{Policy Goals}

The standards set forth in 1990 by UNHCR to assist and protect refugee women and girls were in response to the fact that intervention programs have ineffectively addressed the unique roles, needs, and vulnerable position of this gender. UNHCR recognized the importance of the woman's role as "incomeearner for herself and her family, producer and/or manager of food, provider of fuel and water," and that her "religious, cultural and political activities" (UNHCR, 1990 , p. 5) helped stabilize society. UNHCR also recognized that displacement and the need for asylum affected her ability to fulfill these roles as well as made her and her children vulnerable to sexual, physical, and psychological abuses. The Policy and Guidelines were established to ensure that agencies integrated these essential factors into their assistance and protection programs in order to improve the situation of refugee women and girls (Weise Fagan, 2002). Furthermore, UNHCR recognized that women can be positive agents of change, and in order to fully understand the "protection needs and assistance resources of the [entire] refugee population, and to encourage dignity and self-sufficiency, refugee women 
themselves must participate in planning and implementing projects" (UNHCR, 1990, p. 5).

The Policy's basic principle, then, is to mainstream and integrate "the resources and needs of refugee women in all aspects of program planning and implementation" (UNHCR, 1990, p. 5). The policy's organizational goals are outlined in the UNHCR's High Commissioner's Policy on Refugee Women (UNHCR, 1990, p. 7) as follows:

- To provide protection according to their specific needs;

- To identify an appropriate sustainable solution;

- To provide assistance which will encourage the realization of their full potential and encourage their participation in preparing for the sustainable solution.

Policy objectives are also outlined to give agencies and officials a set of criteria by which to properly interpret the organizational goals. Operational goals are outlined, giving agencies specific activities to implement at the project level to ensure practical application of the policy (UNHCR, 1990).

\section{Major Interest Groups}

Countries and Governments: According to Weiner (1998), donors and respective governments drive the actions of organizations involved in applying the Policy and its Guidelines. UNHCR, for example, must itself take into account the concerns of its donors and of governments whose permission it needs to carry out field operations. UNHCR has found that some donor countries, especially Canada and the United States, have been key advocates for including women's needs for assistance and protection. Canada initiated and funded the Office of the Senior Coordinator for Refugee Women and the United States' Bureau for Population, Refugees and Migration funded the regional gender advisors (Weiss Fagen, 2002).

On the other hand, some governmental regimes are interest groups with a clearly oppositional stand towards the Policy and its Guidelines. Weiss Fagen (2002) points out that some host governments have inadequate expertise in gender-sensitive programming because their own national policies, legislation, and justice systems reinforce gender discrimination or fail to punish SGBV. For example, Mwangi Kagwanja (2000) reports that Kenyan police and soldiers raped women, mostly Somalian, in the Dadaab camp as a form of revenge because unknown gunmen attacked police officers. The Kenyan government never took action against its governmental officials. According to Crawley (2001), the rights of women are particularly at stake in many Middle East Muslim dominated countries under Sharia law. Some years ago, UNHCR faced major problems in refugee camps in Taliban-controlled Afghanistan. The Taliban only consented to 
humanitarian assistance in accordance to Islamic principles; therefore they forbade agencies to employ women, required refugee women to comply with Islamic dress codes, denied girls academic opportunities, and forced women into house-bound subjugation to men (Weiner, 1998). In other countries like Brazil, violence against women is a legal legitimate response seen as a "defense of honor" on the part of the husband (Crawley, 2001).

Non-Governmental Organizations (NGOs): Those who work for humanitarian institutions are usually driven more by humanitarian concerns than are government officials (Weiner, 1998). Numerous NGOs that form the global civil society support the Policy and apply the Guidelines in its practical work by creating and implementing gender-sensitive programming. Examples of such organizations include: World Vision, Oxfam-UK, Kvinna til Kvinna, and Medica Mondiale (Weiss Fagen, 2002). These interest groups still struggle to meet policy guidelines because of conflicting values and ideas within the organization about how to provide adequate protection and equality for refugee women. For example, different attitudes of staff members within the UNHCR agency influence protection policies and guidelines. Some staff members believe that organizations should not interfere with refugee customs, respecting such cultural traditions of refugees as the wearing of the veil, forced marriage, or the neglect to educate girls. Other staff members advocate protecting women against inequality and mistreatment even if this means to act against cultural norms, standards, and taboos (Berthiaume, 1995).

A major supporter of the values enshrined in the Policy and its Guidelines is the European Women's Lobby (EWL). EWL is highly involved in advocacy and policy-making for the rights of women with a special concern for migrant, refugee, minority women. EWL drafted the Gender Equality Road Map for the European Community 2006 - 2010 as a model for the official communication on gender equality in which they called for specific actions to protect migrant and refugee women (EWL, 2005).

Another organization highly involved in the battle for the rights of refugee women is Human Rights Watch (HRW). HRW is monitoring the implementation of the Policy and its Guidelines in problem zones and countries around the world. For example, in a 2003 report titled Trapped by Inequality: Bhutanese Refugee Women in Nepal, HRW examined the uneven response of UNHCR and local government agencies to rape, domestic violence, and sexual assaults on women in Bhutanese refugee camps in southeastern Nepal (HRW, 2003). HRW is one of the NGOs that are participant members in the Executive Committee of UNHCR and is thereby in a position to voice concerns regarding policy issues that address refugee women (UNHCR, 2006). 
A thorough research of the current literature did not yield any results that identify NGOs who profess to be against the Policy and its Guidelines even though it is likely that some conservative religious NGOs whether Islamic (Middle East) or strict Catholic (South America) hold ideology-based preconceptions regarding equal treatment of women.

\section{Diversity, Social Justice, and Ethical Interests}

Although the 1951 Refugee Convention established gender neutral international laws regarding the status and treatment of refugees and their legal rights, interpretation of these laws reflected and reinforced gender bias (Crawley \& Lester, 2004). According to Crawley (2001), women did not "benefit equitably from international protection" (p. 22) because policy interpretations from a male perspective marginalized their experiences. Therefore, the 1990 Policy helped to ensure diversity and social justice among refugees and the 1991 Guidelines provided an ethical reference point to ensure that gender-related and genderspecific assistance and protection programs exist to maximize the experiences of refugee women and girls.

Regarding diversity, UNHCR recognized that "becoming a refugee affects men and women differently" (UNHCR, 1990, p. 5). Men and women carry out different roles in their communities and this diversity needs to be understood and considered when developing programs to assist the entire refugee population. Women are often marginalized because of traditional mindsets, but their duties and activities to the family powerfully hold societies together. Also, men and women become refugees for different reasons. For instance, women flee their homeland because sex slavery and rape as a method of political persecution is a major threat (Walter, 2006). In some countries, patriarchal belief systems cause women to suffer social, religious, and political persecution simply because they are women or because of their feminist beliefs. For example, Mrs. Incirciyan, a widow from Turkey, was harassed and assaulted because her Muslim culture deems it inappropriate for women to live without a male relative (Macintosh, 2005). The 1990 UNHCR protection policy insists that assistance and protection programs address these factors unique to women's experiences.

Regarding social justice, refugee women and girls' rights to live free from discrimination, exploitation, and harassment are often grossly infringed upon. Forced prostitution, trafficking, sexual exploitation, community and family ostracism, female genital cutting (FGC), and sexual and physical violence are just some of the atrocities inflicted on them by family members, community dwellers, and government officials within the camp environment. The Policy and Guidelines, along with other statutes such as the UN Declaration on the Elimination of Violence Against Women and the Convention on the Elimination 
of All Forms of Discrimination Against Women (CEDAW) work together to set minimum human rights standards to protect women and girls against these human rights violations (Crawley \& Lester, 2004). The Policy and Guidelines provide the legal basis that holds key parties accountable to ensure that protection of refugee women is considered in all components of refugee assistance, including education, psycho-social support, social service and community development, income generation, and the design of refugee camps and settlements. (Weiss Fagen, 2003).

The Policy can help sustain and enforce ethical treatment toward refugee women; however, ethical dilemmas occur when various cultural perspectives collide. For instance, the ethics of female genital cutting (FGC) is complex and controversial. World Health Organization (WHO) considers FGC a human rights infringement and in 1997, the enactment of the Federal Prohibition of Female Genital Mutilation Act of 1996 made it a federal crime in the United States. In other cultures, FGC is considered a rite of passage, a cultural norm (Bodley, 2005). Social workers and other professionals in the psychological and medical fields understand the negative consequences of FGC and UNHCR recognizes the need for assistance and protection programs to provide appropriate care for women refugees who have undergone FGC (Elwood, 2005). Nonetheless, aid workers and government officials who grant asylum but do not consider FGC a human rights infringement may not comply with UNHCR policies.

The above mentioned scenario is an example of how, in a general sense, as with any policy, dilemmas arise and political and legal conflicts occur because of a clash of norms. Conflicts can occur within the organization of UNHCR itself as well as among the international community providing aid to the refugee population. UNHCR is in the business of making norms and implementing them. If it cannot adhere to its own norms, it cannot expect to influence governments and humanitarian assistance agencies to conform. Therefore, the success of UNHCR's mandate to protect persecuted individuals is jeopardized when its internationally diverse personnel define and interpret norms and determine how they should be applied based on their own principles if these principles conflict with UNHCR's.

Dilemma also exists when agencies and governments disregard international humanitarian and human rights laws because of a clash of norms. Dilemmas persist when choices have to be made but there seems to be no satisfactory solutions to the issues at hand. Plus, each situation is so "highly contextualized" (Weiner, 1998, p. 440) that it is difficult to consider all the facts and implications before choosing a solution that maximizes policy effectiveness for the target population. One has to ask, are there ever any circumstances when it is acceptable for UNHCR and other humanitarian aid organizations to defer to 
cultural practices that violate international law of human rights? For example, is it ever acceptable to disregard the occurrence of FGC in order to satisfy some other need within the refugee community? In the case of equal opportunities for boys and girls with regard to education in male dominated societies as in Muslim states, should UNHCR mandate Islamic fundamentalists to provide funds to educate girls? It is these kinds of scenarios that human rights policy makers, advocates, and assistance and protection program directors wrestle with to respond appropriately to vulnerable populations (Weiner, 1998).

\section{Policy Outcomes}

The following section draws attention to the positive and unintended outcomes. To guarantee the sustainability of the policy, positive outcomes should outweigh the negative consequences. Moreover, knowledge of drawbacks and gaps helps policy-makers and program directors revise the policy and tackle existing implementation problems to improve its efficiency and effectiveness.

\section{Positive Outcomes}

1. Institutional change in UNHCR: In 1993 the Department of International Protection created the post of Legal Advisor for Refugee Women and Children. The Legal Advisor provides legal counsel, guidance for governments, training materials and guidance for field staff and guidance on adjudication of gender-related asylum claims (Weiss Fagen, 2002).

2. Development of new programming tools: An immediate outcome of the Policy was the creation of the Guidelines on the Protection of Refugee Women published in 1991. They outline various measures to improve the protection of refugee women, how to prevent and deter protection problems from arising, how to help women whose rights have been violated, and how to report upon protection problems (UNHCR, 1991).

Other programming tools built on the foundation of the Policy include the following:

- The People - Oriented Planning (POP) is a framework to analyze the socio-cultural and economic factors in a refugee society which can influence the success of planned activities. (Anderson, Howarth \& Overholt, 1992).

- In 1995 UNHCR published Sexual Violence against Refugees: Guidelines on Prevention and Response with the goal to create a greater awareness of the serious human rights violations against women and as a foundation for developing programs for adequate response. The 1995 Guidelines were thoroughly reviewed by the 2001 Inter Agency Conference in Geneva, Switzerland, and were updated and republished in 2003 following 
comprehensive field-tests in 32 countries around the world (UNHCR, 2003).

- In 2002 the UNHCR Gender Guidelines were adopted by the Executive Commission and designed as a gender-sensitive interpretation of the 1951 Refugee Convention to provide sexual and gender-based persecuted women the legal bases for filing an asylum petition (UNHCR, 2002; Crawley \& Lester, 2004).

3. Improvement of refugee women situation: The Women's Commission for Refugee Women and Children conducted a comprehensive assessment of the implementation of the UNHCR Policy and its Guidelines and found that they successfully enhanced protection activities such as improvement in the determination of gender-sensitive refugee status, more vigorous use of national laws to enforce women's human rights, and improved registration mechanism for refugee women. Furthermore, a variety of assistant efforts to promote the protection of women resulted from the Guidelines such as including women in refugee camp management, direct involvement of women in food distribution, wider available reproductive health service, and counseling service for female victims of trauma or violence (Weiss Fagen, 2002). Some region-specific examples for the improvement of refugee women's situation according to Weiss Fagen (2002) are:

- In Pakistan refugee camps, female health workers have been employed to assist the special needs for women.

- The UNHCR protection officers in Turkey reported successes with regard to the protection of women's human rights.

- In Pakistan, workshops on human rights, including women's rights, were conducted by using the religious law from the Koran and thereby placing the program effectively within the cultural context.

- In Zambia, joint gender training of Community Services and Protection staff, including NGO staff, government officials, police officers, and immigration staff, was successfully implemented.

- In Afghanistan, girls school attendance and access has improved significantly

\section{Unintended Outcomes}

1. Moral decay: Turner (2000) conducted interviews in a Burundian refugee camp where the Policy and its Guidelines were implemented and found that divorce rates had gone up and polygamy as well as prostitution had increased. The Burundians themselves explained that the reason for this tendency was that women became less dependent and no longer respected their husbands. The 
ideology of gender equality was seen by the African refugees as a threat to their masculinity with UNHCR taking their place as husbands and fathers.

2. Opposition to Cultural Norms: In some countries, even young, educated women believe that men are supposed to be masters and that equality only creates problems (Turner, 2000). Thus, the Policy, with its emphases on gender equality, seems to work contrary to cultural norms and belief systems and thus may be not be sustainable in the long run.

3. Opposition to Religious Beliefs: Especially in Muslim dominated regions, a strong emphasis on women may cause religious problems. For example, in a Sri Lankan refugee camp the emphasis of a particular NGO to employ women was too radical for the mosque trustee board and the women employees were subsequently shunned (Brun, 2000). In this way, a strong gender focus due to the Policy may result in the failure of certain programs.

4. One-sidedness: The Policy's strong focus on women has led to a onesided emphasis resulting in the oversight of young men (Brun, 2000). This onesidedness causes averseness and envy and may result in a further separation of the genders. Thus, Walby (2005) calls for a gender mainstreaming approach rather than separating the target groups with a sole focus on women.

5. Negative conception: Another problem may be that the Policy leads to the general perception of women only as victims. Refugee women are presented as uniformly poor, powerless, and vulnerable (Crawley, 2000). This underlying view may result in a diminishing of the self-esteem of women and may pigeonhole them as helpless subjects rather than as persons with human dignity and inherent self-worth.

\section{Global Comparison}

The United States (US), Canada, and the United Kingdom (UK) are among the top nations that assist and protect refugees; asylum-seekers flee to these industrialized areas in hopes of finding aid and freedom from persecution. This section is an analysis of how well these governments assist and protect refugee women in comparison to the governments where the majority of asylumseekers originate.

UNHCR reports little statistical data about efforts made toward meeting its criteria and standards for refugee women and girls set forth in the 1990 Policy. UNHCR's 2007 Global Report (UNHCR, 2008) offers only general statements that indicate some effort is being made to address gender issues. For example, in the report on the Americas, it only states that "In Costa Rica...the House of Rights...seeks to prevent and respond to sexual and gender-based violence" (UNHCR, 2008, p. 134-135). In addition, the UNHCR 2008-2009 Global Appeal highlights several goals and objectives for assisting and protecting refugee women 
and girls, but it does not offer any concrete actions to ensure them. Therefore, the authors chose to construct a comparative analysis of what is actually happening in the field from case studies reported in articles scattered throughout various publications.

In the US, both the Women's Commission for Refugee Women and Children (WCRWC) and the Lutheran Immigration and Refugee Service (LIRS) reported in February, 2007, that women and their families were housed in prisonlike conditions at the T. Don Hutto Residential Center in Texas and the Berks Family Shelter Care Facility in Pennsylvania (McKenna \& Champion, 2007). Women and children who fled their country of origin seeking refuge from torture failed to receive adequate medical and mental health care, education, sanitary living conditions, and freedom to move around the facility or go outside. Obviously, these conditions do not meet the Policy's criteria for assistance and protection. Nonetheless, the Future Group (2006) states that the US government is complying with international guidelines to assist and protect victims of trafficking by working with NGOs to provide the medical and psychological support these women need.

In Canada, conditions for refugee women and their families are bleak. Dyck and McLaren (2004) present a case study of an Iranian woman who fled her homeland because of religious persecution. She hoped to find refuge in Vancouver, but she claims she had only experienced more hardship and persecution because of her refugee status. She was not able to secure employment, she did not feel safe, and she had become ill because of the stress and was not able to receive proper health care. These conditions and experiences left this woman marginalized and vulnerable. In addition, the Future Group (2006) reports that the Canadian government and private NGOs have failed to provide protection and support to human trafficking victims.

In the UK, according to an article by Walter (2006) entitled, "Rape by Soldiers - Isn't that Persecution?", England's adjudicators do not think that sexual violence and persecution such as FGM, forced marriage, sex trafficking, and threats of honor-killing from soldiers, husbands, and family members fall under the asylum laws of the 1951 Refugee Convention. Therefore, many women seeking refuge in the UK are refused asylum and end up living on the streets or in prison. According to the Future Group (2006), the UK provides only minimal support to victims of trafficking. Crawley and Lester (2004) indicate that the UK's Immigration Appellate Authority's (IAA) Gender Guidelines are the most comprehensive official Gender Guidelines in Europe, but decision-makers are not bound by them when interpreting gender-sensitive persecution. Grassroots efforts, such as those by the Women for Refugee Women campaign, have formed to raise awareness and encourage Britain to honor the rights of women who flee rape and 
other kinds of gender-related persecution by giving them refugee status (Walter, 2006).

With regard to the asylum-seekers' places of origin, Asia ranks highest, contributing approximately 45 percent of all asylum applications submitted by individuals, with the majority of applications submitted by Iraqis requesting refugee status (UNHCR, 2009). Africa ranks second, contributing approximately 30 percent of all individuals seeking protection, with the majority of applications submitted by people from Somalia requesting refugee status (UNHCR, 2009).

Asia and Africa are both considered opponents of the Policy, mainly because of traditional mindsets and internal conflict. It is difficult for any organization in these areas of the globe to meet the Policy's standards for refugee women. Nonetheless, UNHCR reports that it has had some success fulfilling the Policy's goals. Despite limited access to refugee populations and security concerns near several UNHCR camps in Iraq, UNHCR (2008) reports that an average of 50 percent of its total aid to refugees went to women. UNHCR's overall assessment for Somalia in 2007 (UNHCR, 2008) is that it could not "fully implement its 2007 programmes" (p. 231) due to security concerns, but it was able to provide medical and psychological support to 160 victims of sexual and gender-based violence in three IDP settlements and distribute approximately 600 packages of sanitary materials to women of childbearing age.

In summary, these articles reveal that although plenty seems to be going on with regard to policy-making, the countries whose governments have willingly adopted UNHCR's Policy on Refugee Women offer minimal efforts to provide assistance and protection that effectively addresses gender-specific issues. In addition, it seems that UNHCR and other NGOs focus their attention primarily on locations where governments are not cooperative and in fact create the majority of the refugee population.

\section{Conclusion and Recommendations}

Almost 60 years have passed since UNHCR established the legal basis for protecting the fundamental rights of refugees, and almost 20 years since the special circumstances of women and girls in this population were legally recognized. Despite the support of major industrialized nations, of huge amount of governmental policies, and the creation of governmental and non-governmental organizations to fulfill professed goals and objectives, it seems that little has been accomplished in the field. UNHCR continues to lead the way, but without proper implementation by all supportive agencies and interest groups, this vulnerable population continues to be marginalized on many levels. In light of the presented evidence, the authors make these recommendations: 
- Encourage senior managers in the field to ensure implementation of the Policy and its Guidelines and train field officers in gender-based programs.

- Encourage donors to increase refugee funding, with a special focus on supporting the principles of the Policy. Make more funding available for gender-based training and increase the number of field staff to support the women.

- Increase the number of female UNHCR staff in the refugee camps to that better represent the population at large.

- Develop a UNHCR gender mainstreaming/gender equality policy.

- Improve the demographic information with accurate information disaggregated by gender. This could be done by the wider use of refugee registration cards containing information such as name, gender, vulnerability code, family affiliation, and biometric data.

- Give more power to the International Criminal Court which can persecute gender-related crimes and crimes of sexual violence.

- Execute a more thorough monitoring and evaluation system of the implementing agencies to ensure a more even and complete distribution of services throughout the world.

- Establish specific activities to accomplish policy objectives that reinforce accountability regarding implementation.

- Decrease SGBV by implementing programs that target the source of the problem while also addressing the symptoms and consequences.

By following these recommendations, the situation of refugee women could be effectively improved. Moreover, the enhanced integration and advancement of women's issues in the activities of a greater number of NGOs and governmental organizations could have a radiating global impact, resulting in the equal treatment of men and women and the fostering of mutual respect and tolerance among genders. 


\section{References}

Anderson, M. (1993). Focusing on women: UNIFEM's experience in mainstreaming [Abstract]. New York, NY: United Nations Development Fund for Women.

Bodley, J. H. (2005). Cultural anthropology: Tribes, states, and the global system (4th ed.). New York: McGraw-Hill.

Berthiaume, C. (1995). Do we really care? Refugee Women. Refugees Magazine, $100,10-13$.

Brun, C. (2000). Making young displaced men visible. Forced Migration Review, 9, 10-12.

Crawley, H. (2000). Gender, persecution and the concept of politics in the asylum determination process. Forced Migration Review, 9, 17-20.

Crawley, H. (2001). Refugee and gender: Law and process. Bristol, U.K.: Jordan Publishing Limited.

Crawley, H., \& Lester, T. (2004). Comparative analysis of gender-related persecution in national asylum legislation and practice in Europe. Evaluation and Policy Analysis Unit Evaluation Report EPAU/2004/05. Geneva, Switzerland: Author.

Dyck, I., \& McLaren, A. T. (2004, December). Telling it like it is? Constructing accounts of settlement with immigrant and refugee women in Canada. Gender, Place and Culture, 11(4), 513-534.

Elwood, A. (2005, January). Female genital cutting, 'circumcision' and mutilation: Physical, psychological and cultural perspectives. Contemporary Sexuality, 39(1), 11.

EWL, European Women's Lobby. (2005, November). Gender Equality Road Map for the European Community. Brussels, Belgium: Author. Retrieved February 17, 2009 from http://www.womenlobby.org/SiteResources/data/MediaArchive/policies/g ender\%20equality/EWL\%20Road\%20Map\%20_EN.pdf.

Future Group, The (2006, March). Falling short of the mark: An international study on the treatment of human trafficking victims. The Future Group Publications Division, Alberta, Canada. Retrieved April 5, 2009 from http://www.thefuturegroup.org.

Gururaja, S. (2000). Gender dimensions of displacement. Forced Migration Review, 9, 13-16. 
HRW, Human Rights Watch. (2003, September 23). Nepal/Bhutan: Refugee Women Face Abuses. New York: Author. Retrieved February 17, 2009 from http://www.hrw.org/en/news/2003/09/23/nepalbhutan-refugeewomen-face-abuses.

Jahan, R. (1996). The elusive agenda: Mainstreaming women in development. The Pakistan Development Review, 35(4), 825-834.

Macintosh, C. (2005). When "feminist beliefs" became credible as "political opinions": Returning to a key moment in Canadian refugee law. Canadian Journal of Women \& the Law, 17(1), 135-150.

Mwangi Kagwanja, P. (2000). Ethnicity, gender and violence in Kenya. Forced Migration Review, 9, 22-25.

Turner, S. (2000). Vindicating masculinity: the fate of promoting gender equality. Forced Migration Review, 9, 8-10.

UN, United Nations (1985). Nairobi Forward-looking strategies for the advancement of women. World Conference, Nairobi, Kenya: Author. Retrieved February 18, 2009 from http://www.undocuments.net/nflsaw.htm.

UNHCR, United Nations High Commissioner for Human Rights (1951). Convention relating to the status of refugees. Geneva, Switzerland: Author.

UNHCR, United Nations High Commissioner for Human Rights (1979). Convention on the elimination of all forms of discrimination against women. Geneva, Switzerland: Author. Retrieved February 13, 2009 from http://www.unhchr.ch/html/menu3/b/e1cedaw.htm.

UNHCR, United Nations High Commissioner for Refugees (1990). UNHCR Policy on refugee women. Geneva, Switzerland: Author.

UNHCR, United Nations High Commissioner for Refugees (1990). UNHCR Policy on refugee women. Geneva, Switzerland: Author. Retrieved April 5, 2009 from http://www.unhcr.org/excom/EXCOM/3b9cd20e5.pdf.

UNHCR, United Nations High Commissioner for Refugees (1991). Guidelines on the protection of refugee women. Geneva, Switzerland: Author.

UNHCR, United Nations High Commissioner for Refugees (2002). Guidelines on the international protection: Gender-related persecution within the context of article $1 \mathrm{~A}(2)$ of the 1951 Convention and/or its 1967 Protocol relating to the Status of Refugees. Geneva, Switzerland: Author. 
UNHCR, United Nations High Commissioner for Refugees (2003). Sexual and gender-based violence against refugees, returnees and internally displaced persons: Guidelines for prevention and response. Geneva, Switzerland: Author. Retrieved February 18, 2009 from http://www.unhcr.org/cgibin/texis/vtx/protect/opendoc.pdf?tbl=PROTECT ION\&id=3f696bcc 4 .

UNHCR, United Nations High Commissioner for Refugees (2003, October). Agenda for protection. Geneva, Switzerland: Author. Retrieved March 29, 2009 from http://www.unhcr.org/protect/PROTECTION/3e637b194.pdf.

UNHCR, United Nations High Commissioner for Human Rights (2006). Executive committee of the High Commissioner's programme (Fiftyseventh session). Geneva, Switzerland: Author. Retrieved February 17, 2009 from http://www.unhcr.org/excom/EXCOM/452cf2e42.pdf.

UNHCR, United Nations High Commissioner for Human Rights (2008, January). UNHCR Handbook for the protection of women and girls. Geneva, Switzerland: Author. Retrieved March 6, 2009 from http://www.unhcr.org/protect/PROTECTION/47cfa9fe2.pdf.

UNHCR, United Nations High Commissioner for Human Rights (2008, June). UNHCR Global report 2007. Geneva, Switzerland: Author. Retrieved April 5, 2009 from http://www.unhcr.org/gr07/index.html.

UNHCR, United Nations High Commissioner for Human Rights (2008, November). UNHCR Global appeal 2009 update. Geneva, Switzerland: Author. Retrieved April 5, 2009 from http://www.unhcr.org/ga09/index.html.

UNHCR, United Nations High Commissioner for Human Rights (2008, December). Refugee protection and human trafficking: Selected legal reference materials. Geneva, Switzerland: Author. Retrieved March 29, 2009 from http://www.unhcr.org/publ/PUBL/4986fd6b2.pdf.

UNHCR, United Nations High Commissioner for Human Rights (2009, March 13). UN expert says world is neglecting major internal displacement crisis [press release]. Geneva Switzerland: Author. Retrieved March 29, 2009 from

http://www.unhcr.ch/hurricane/hurricane.nsf/view01/30D38D2A6F00BB4 1C1257578004BBBF7?opendocument.

UNHCR, United Nations High Commissioner for Human Rights (2009, March 24). Asylum levels and trends in industrialized countries 2008: Statistical overview of asylum applications lodged in Europe and non-European 
countries. Geneva, Switzerland: Author. Retrieved April 5, 2009 from http://www.unhcr.org/statistics/STATISTICS/49c796572.pdf.

Walby, S. (2005). Gender mainstreaming: Productive tensions in theory and practice. Social Politics, 12(3), 321-343.

Walter, N. (2006, May 15). Rape by soldiers - isn't it persecution? New Statesman, 135(4792) 32-33. Weiner, M. (1998). The clash of norms: dilemmas in refugee policies. Journal of Refugee Studies, 11(4), 433-453.

Weiss Fagen, P. (2002). UNHCR policy on refugee women and guidelines on their protection: An assessment of ten years of implementation. New York: Women's Commission for Refugee Women and Children.

Weiss Fagen, P. (2003). Protecting refugee women and children. International Migration, 41(1), 75-86. 